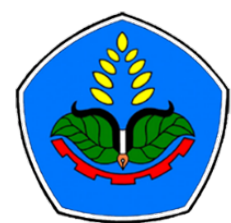

AGROPROSS

National Conference

Proceedings of Agriculture

\title{
Proceedings:
}

Peningkatan Produktivitas Pertanian Era Society 5.0 Pasca Pandemi

Tempat : Politeknik Negeri Jember

Tanggal : 22 Juli 2021

Publisher :

Agropross, National Conference Proceedings of Agriculture

ISBN : 978-623-94036-6-9

DOI : 10.25047 /agropross.2021.214

\section{Respon Pertumbuhan dan Hasil Jagung (Zea mays L.) Dalam Sistem Tumpangsari dengan Beberapa Jenis Tanaman Semusim}

\author{
Author(s): Saraswati Prabawardani ${ }^{(1)^{*}}$, Leonora Puadi ${ }^{(2)}$, Alce Ilona Noya ${ }^{(1)}$, Sutiharni ${ }^{(1)}$, \\ Siska Syaranamual ${ }^{(1)}$, \\ (1) Program Studi Agroteknologi, Fakultas Pertanian Universitas Papua \\ (2) Dinas Tanaman Pangan, Hortikultura dan Perkebunan Propinsi Papua Barat \\ * Corresponding author: s.prabawardani@unipa.ac.id
}

\section{ABSTRACT}

In an effort to increase productivity, corn has the potential to be developed in an intercropping pattern. In addition to increasing production, intercropping is considered an environmentally friendly cultivation method and is commonly practiced by farming communities in Papua. The experiment of maize intercropping with several other seasonal crops is still limited. This study aims to examine the growth response and yield of maize intercropped with other types of seasonal crops. The research was carried out in the experimental field and the Agro-climate Laboratory, Faculty of Agriculture, Papua University in 2018. The study used a randomized block design with 8 treatments and 3 replications. The treatment consisted of a combination of intercropping corn with several other types of crops, namely: corn monoculture (control), corn + spinach, corn + taro, corn + beans, corn + sweet potato, corn + peanut, corn + red onion, and corn + kale. Observation variables consisted of plant height, number of leaves, stem diameter, weight of plant biomass, length, diameter and weight of cobs. The data were analyzed using analysis of variance with a 95\% confidence level, and if the results had a significant effect, then it was further tested with the smallest significant difference test $(B N T)=5 \%$. The results showed that the single corn cultivation system (corn monoculture) produced the highest plant height, number of leaves and stem diameter, but the yield component showed the lowest average cob weight per plant. The yield component (mean length of cob, diameter of cob and weight of cob per plant) showed that intercropping corn + kale resulted in the highest cob weight per plant, followed by corn + sweet potato, corn + spinach and corn + shallots and corn + peanuts, although statistically was not different.
\end{abstract}

\section{Keywords:}

annual plants;

corn;

intercropping;

monoculture;

Zea mays

\section{Kata Kunci: ABSTRAK}

jagung;

monokultur;

tanaman

semusim;

tumpangsari;

Zea mays
Dalam upaya meningkatkan produktifitas, tanaman jagung sangat berpotensi untuk dikembangkan dalam pola tanam tumpangsari. Selain untuk meningkatkan produksi, pola tumpangsari dipertimbangkan sebagai metode budidaya yang ramah lingkungan dan umum dipraktekkan oleh masyarakat petani di Papua. Pengujian tumpangsari jagung dengan tanaman sela dari beberapa jenis tanaman semusim lainnya masih terbatas. Penelitian ini bertujuan untuk mengkaji respon pertumbuhan dan hasil jagung yang ditumpangsari dengan jenis-jenis tanaman semusim lainnya. Penelitian dilaksanakan di kebun percobaan dan Laboratorium Agroklimat Fakultas Pertanian Universitas Papua pada tahun 2018. Penelitian menggunakan Rancangan Acak Kelompok dengan 8 perlakuan dan 3 ulangan. Perlakuan terdiri dari kombinasi tumpangsari jagung dengan beberapa jenis tanaman lainnya, yaitu : Monokultur jagung (kontrol), tumpangsai jagung+bayam, jagung+keladi, jagung+buncis, jagung+ubijalar, jagung + kacang tanah, jagung+bawang merah, dan jagung + kangkung. Variabel pengamatan terdiri dari tinggi tanaman, jumlah daun, diameter batang, berat brangkasan tanaman, panjang, diameter dan berat tongkol. Data dianalisis menggunakan analisis ragam dengan taraf kepercayaan $95 \%$, dan apabila hasilnya berpengaruh nyata dilanjutkan dengan uji beda nyata terkecil (BNT) $\alpha=5 \%$. Hasil penelitian menunjukkan bahwa sistim budidaya tunggal jagung menghasilkan tinggi tanaman, jumlah daun dan diameter batang tertinggi, namun pada komponen hasil menunjukkan rata-rata bobot tongkol per tanaman terendah. Pada komponen hasil (rata-rata panjang tongkol, diameter tongkol dan berat tongkol per tanaman) menunjukkan tumpangsari jagung+kangkung menghasilkan berat tongkol jagung per tanaman tertinggi, diikuti oleh jagung+ubijalar, jagung+bayam dan jagung+bawang merah dan jagung+kacang tanah, walaupun secara statistic tidak berbeda nyata. 


\section{PENDAHULUAN}

Jagung (Zea mays L.) merupakan salah satu komoditas pangan yang memiliki potensi tumbuh dan berkembang pada berbagai jenis tanah dan banyak dibudidayakan oleh masyarakat Indonesia termasuk masyarakat di Papua. Jagung dikenal sebagai tanaman semusim yang merupakan tanaman pangan penghasil karbohidrat selain gandum dan padi. Luas tanam jagung nasional hingga tahun 2020 mencapai 5,5 juta hektar (ha), luas panen jagung nasional mencapai 5,16 juta ha dan potensi produksi dapat mencapai 11 ton/ha (Santia, 2021). Produktifitas jagung di Papua Barat masih rendah, yaitu 17,24 $\mathrm{kw} / \mathrm{ha}(1,7 \mathrm{ton} / \mathrm{ha})$ pada tahun 2014 (BPS Papua Barat, 2015) bila dibandingkan dengan produktifitas nasional $(3,06$ ton/ha) pada tahun yang sama (Kementerian Pertanian RI, 2016). Namun, data produktifitas jagung di Papua Barat pada lima tahun ini terakhir tidak tersedia. Upaya peningkatan produksi jagung terus didorong untuk memenuhi kebutuhan masyarakat, industri pangan dan pakan ternak.

Salah satu cara untuk meningkatkan produksi tanaman pangan yaitu dengan menerapkan pola tanam tumpangari atau tanaman campuran dengan berbagai jenis tanaman. Namun dalam pola tanam tumpangsari perlu memperhatikan tanggap tanaman terhadap persaingan dalam proses pertumbuhan dan perkembangan, karena dalam periode tertentu berbagai tanaman sangat sensitif berkompetisi dalam mendapatkan unsur hara dan faktor lainnya yang menunjang pertumbuhan dan perkembangan tanaman (Herlina et al., 2011). Dengan demikian maka pengaturan jenis tanaman dan proses penanaman perlu diatur dan dikelola dengan baik agar persaingan antar jenis tanaman yang ditumpangsari dapat ditekan sekecil mugkin.

Lahan pertanian pada saat ini ketersediannya semakin terbatas, sehingga untuk budidaya jagung selain upaya intensifikasi, tumpangsari merupakan alternatif lainnya dalam memaksimalkan produktifitas dan efisiensi lahan (Surtinah et al. 2016). Tumpangsari adalah bentuk pola tanam yang membudidayakan lebih dari satu jenis tanaman dalam satuan waktu tertentu. Pola tanam ini merupakan salah satu bentuk dari program intensifikasi pertanian dengan tujuan untuk memperoleh produksi yang optimal, menjaga kesuburan tanah dan mengurangi resiko kegagalan salah satu tanaman campuran, dan hasil dari kombinasi tanaman per satuan luas dapat lebih tinggi dari sistem monokultur apabila komposisi tanaman dan jarak tanam dalam pola tumpangsari ditata dengan tepat (Ekayujaya, 2019). Tumpangsari juga bertujuan untuk mengoptimalkan penggunaan hara, air dan sinar matahari seefisien mungkin guna mendapatkan produksi maksimum (Prasetyo et al., 2009).

Tumpangsari dapat menimbulkan interaksi sebagai respon dari masingmasing tanaman yang membutuhkan ruang yang memadai untuk memaksimalkan kerja sama dan menekan kompetisi sekecil mungkin, sehingga pengaturan jarak tanam, populasi tanaman, umur panen tiap tanaman dan arsitektur tanaman perlu mendapat perhatian dari pola tanam ini (Sulivan, 2003). Surtinah et al. (2016) menambahkan bahwa untuk mengurangi kompetisi dalam tumpangsari maka perlu pengaturan penggunaan jenis tanaman yang ditumpangsarikan dan waktu tanam yang sesuai. Selain untuk tujuan efisiensi pemanfaatan lahan, memanfaatkan faktor produksi secara optimal (misalnya keterbatasan lahan, tenaga kerja, modal kerja), pemakaian pupuk dan pestisida lebih efisien, mengurangi evaporasi dan erosi, mengurangi resiko kegagalan salah satu tanaman, stabilitas biologi tanah dan mendapatkan produksi total yang lebih besar (Tharir dan Hadmadi, 1984 dalam 
Prasetyo et al., 2009), dan pemilihan kombinasi jenis tanaman sela sangat menentukan keberhasilan tumpangsari (Warsana, 2009).

Kompetisi diantara tanaman atau jenis tanaman yang ditanam secara tumpangsari dapat terjadi pada bagian tajuk dalam persaingan mendapatkan cahaya dan akar tanaman dalam persaingan untuk mendapatkan air dan hara sehingga dapat mempengaruhi pertumbuhan dan hasil tanaman (Coolman dan Hoyt, 1993). Penerimaan cahaya oleh tanaman yang sangat ternaungi akan terbatas, padahal cahaya mempunyai fungsi vital dalam reaksi metabolisme yang menentukan pertumbuhan dan hasil tanaman. Demikian pula akar memiliki peran yang sama penting dengan bagian atas tanaman (tajuk), dalam menyediakan hara dan air bagi metabolism tanaman. Sistim perakaran yang dalam dan bercabang luas atau volumenya besar lebih mempunyai aksesibilitas dalam persaingan memperebutkan air (Passioura, 2002). Selain mengurangi persaingan dalam penyerapan air, maka tanaman yang ditumpangsarikan sebaiknya memiliki sistem perakaran dengan kedalaman yang berbeda untuk menghindari terjadinya persaingan unsur hara (Zulkarnain, 2005). Namun, besarnya kompetisi ini tergantung pada berbagai faktor termasuk waktu tanam, jenis tanaman dan daya atau kemampuan masing-masing tanaman yang ditumpangsarikan untuk saling meningkatkan produktifitas masingmasing tanaman. Sehingga penelitian ini bertujuan untuk mengkaji respon pertumbuhan dan hasil jagung yang ditumpangsari dengan jenis-jenis tanaman semusim lainnya.

\section{BAHAN DAN METODE}

Penelitian dilaksanakan di kebun percobaan dan laboratorium Agroklimat Fakultas Pertanian Universitas Papua pada tahun 2018. Lokasi penelitian terletak pada ketinggian 110 meter dari permukaan laut. Sebanyak 8 jenis tanaman yaitu jagung varietas hibrida, kacang tanah varietas lokal, ubijalar varietas lokal, talas (keladi) varietas lokal, bawang merah varietas lokal, buncis varietas hibrida, bayam varietas hibrida, dan kangkung varietas hibrida. Pupuk dasar yang digunakan pada awal pertanaman berupa pupuk Papua Nutrient Granul 10 gram/tanaman, dan abu dapur digunakan sebagai pengusir semut merah saat awal penanaman benih.

Penelitian menggunakan metode eksperimen dalam Rancangan Acak Kelompok dengan 8 (delapan) perlakuan dan 3 (tiga) kali ulangan. Perlakuan terdiri dari kombinasi tumpangsari jagung dengan beberapa jenis tanaman lainnya, sebagai berikut : (1) Monokultur jagung (kontrol), (2) Tumpangsai jagung + bayam, (3) Tumpangsari jagung + keladi, (4) Tumpangsari jagung + buncis, (5) Tumpangsari jagung + ubijalar, (6) Tumpangsari jagung + kacang tanah, (7) Tumpangsari jagung + bawang merah, (8) Tumpangsari jagung + kangkung.

Pelaksanaan penelitian dilakukan dalam beberapa tahap, yaitu : (1) Persiapan Lahan dan Pengolahan Tanah. Pada persiapan lahan, pertama-tama dilakukan pembersihkan semak rumput yang tumbuh di sekitar lahan dengan menggunakan parang, arit dan garu. Kemudian rumput atau semak-semak tersebut disisihkan ke samping areal percobaan lalu dibakar. Selanjutnya lahan diukur dengan panjang 28 meter dan lebar 10 meter, dan dibagi menjadi masing-masing petak perlakuan sebanyak 8 petak dengan ukuran $2 \mathrm{~m}$ x $3 \mathrm{~m}$ dan jarak antar bedeng $50 \mathrm{~cm}$, tinggi $30 \mathrm{~cm}$ sebanyak 24 petak; (2) Persiapan Bahan Tanam dan Jarak Tanam. Benih yang disiapkan untuk ditanam yaitu benih jagung, bayam, anakan keladi, buncis, stek ubijalar kacang tanah, bawang merah dan kangkung. Benih dan bahan tanam stek pucuk ubijalar dan anakan keladi berkualitas baik, tidak cacat atau rusak. 
Jarak tanam dalam baris antara jagung dan masing-masing tanaman pendamping adalah $50 \mathrm{~cm}$, sedangkan jarak antar bedeng $100 \mathrm{~cm}$; (3) Penanaman dan Pemupukan. Penanaman dilakukan dengan cara benih dimasukan sebanyak 2-3 benih ke dalam lubang tanam, dan kemudian ditutup dengan lapisan atas tanah. Demikian pula stek pucuk ubijalar dan bibit keladi ditanam pada setiap lubang tanam yang telah dibuat atau dipersiapkan. Pada perlakuan tumpangsari jagung, tanaman pendamping yaitu bayam, kangkung, buncis, kacang tanah, keladi, ubijalar ditanam dilakukan pada umur 1 minggu setelah tanam jagung. Pemupukan diberikan melingkari lubang tanam jagung dan beberapa tanaman lainnya pada saat bersamaan.; (4) Pemeliharaan. Pemeliharaan tanaman meliputi penyulaman dilakukan pada umur 1 minggu setelah tanam apabila ada bibit yang mati. Penjarangan tanaman jagung dan tanaman pendamping lainnya menjadi 1 tanaman dilakukan juga pada umur 1 minggu setelah tanam. Penyiraman dilakukan pada sore hari apabila tidak turun hujan hingga mendekati akhir masa generatif dan penyiangan dilakukan setiap 2 minggu sekali; (5) Pemanenan. Pemanenan dilakukan pada waktu rambut pada tongkol jagung berwarna coklat tua yang menunjukkan tanda bahwa sudah siap untuk dipanen pada umur 3 bulan setelah tanam untuk tanaman jagung. Tanaman pendamping yaitu kangkung dipanen pada umur 3 minggu setelah tanam, bayam pada umur 1,5 bulan setelah tanam, buncis pada umur 2,5 bulan setelah tanam, kacang tanah dan bawang merah pada umur 3 bulan setelah tanam, ubijalar dipanen pada umur 4 bulan setelah dan keladi pada umur 8 bulan setelah tanam.
Pengamatan dilakukan pada masingmasing variabel pada 4 tanaman contoh perpetak, meliputi : (1) Komponen pertumbuhan yang terdiri dari variabel : Tinggi tanaman jagung $(\mathrm{cm})$ pada umur 1 , 2, 3, 4, 5, 6 minggu setelah tanam, Jumlah daun per tanaman pada umur 1, 2, 3, 4, 5, 6 minggu setelah tanam, Diameter batang (mm), diukur pada pangkal batang, pada umur 6 minggu setelah tanam, Bobot brangkasan kering per tanaman (gram); (2) Komponen produksi terdiri dari variabel : Panjang tongkol tanpa kelobot $(\mathrm{cm})$, Diameter tongkol tanpa kelobot $(\mathrm{cm})$, Bobot tongkol tanpa kelobot per tanaman (gram/tongkol).

\section{Analisis Data}

Data penelitian dianalisis dengan menggunakan analisis ragam dengan taraf kepercayaan $95 \%$ untuk mengetahui pengaruh perlakuan, dan apabila hasilnya berpengaruh nyata maka dilanjutkan dengan uji beda nyata terkecil (BNT) $\alpha=$ $5 \%$.

\section{HASIL DAN PEMBAHASAN}

Hasil analisis ragam terhadap sistim budidaya jagung pola tunggal (monokultur) dan pola tanaman campuran (tumpangsari) antara jagung dengan beberapa tanaman lainnya, yaitu bayam, keladi, buncis, ubijalar, kacang tanah, bawang merah dan kangkung menunjukkan pengaruh yang nyata dan sangat nyata terhadap beberapa variabel dari komponen pertumbuhan, yaitu tinggi tanaman, jumlah daun dan diameter batang, sedangkan komponen produksi yaitu diameter tongkol, panjang tongkol dan bobot kering jagung tanpa kelobot tidak menunjukkan pengaruh nyata (Tabel $1)$. 
Tabel 1 Tabel 1. Rekapitulasi sidik ragam dan koefisien keragaman (\%)

\begin{tabular}{lcc}
\hline Karakter & Pr-F & $\begin{array}{c}\text { Koefisien } \\
\text { keragaman } \\
(\mathbf{\%})\end{array}$ \\
\hline Tinggi tanaman 1 MST & $0,0306^{*}$ & 9.28 \\
Tinggi tanaman 2 MST & $0,0003^{* *}$ & 7.35 \\
Tinggi tanaman 3 MST & $0,0012^{* *}$ & 9.99 \\
Tinggi tanaman 4 MST & $0,0019^{* *}$ & 11.13 \\
Tinggi tanaman 5 MST & $0,0028^{* *}$ & 11.68 \\
Tinggi tanaman 6 MST & $0,0030^{* *}$ & 11.86 \\
Jumlah daun 1 MST & $0,0018^{*}$ & 5.88 \\
Jumlah daun 2 MST & $0,0062^{* *}$ & 7.41 \\
Jumlah daun 3 MST & $0,0003^{* *}$ & 7.86 \\
Jumlah daun 4 MST & $0,0014^{* *}$ & 7.77 \\
Jumlah daun 5 MST & $0,0015^{* *}$ & 7.14 \\
Jumlah daun 6 MST & $0,0022^{*}$ & 7.64 \\
Diameter batang 6 MST & $0,0001^{* *}$ & 13.90 \\
Bobot brangkasan kering tanaman & $0,5082^{\text {ns }}$ & 7.15 \\
Diameter tongkol tanpa kelobot & $0,2638^{\text {ns }}$ & 9.38 \\
Panjang tongkol jagung tanpa kelobot & $0,1883^{\text {ns }}$ & 10.36 \\
Berat tongkol jagung tanpa kelobot & $0,6434^{\text {ns }}$ & 5.63 \\
\hline Kerang
\end{tabular}

Keterangan : $* *=$ sangat signifikan apabila p-value $<0,001 ; *=$ signifikan apabila $\mathrm{p}$-value $<0,005 ; \mathrm{ns}=$ non signifikan apabila $\mathrm{p}$-value $>0,005 ; \mathrm{MST}=$ minggu setelah tanam)

\section{Tinggi Tanaman}

Hasil uji Beda Nyata Terkecil (BNT) pada variabel tinggi tanaman (Tabel 2) menunjukkan bahwa pada minggu pertama setelah tanam perlakuan pola tunggal (monocropping) jagung menghasilkan tanaman lebih tinggi dibandingkan dengan perlakuan tanam tumpang sari/tumpang gilir, namun tidak berbeda nyata dengan perlakuan tanam kombinasi jagung + kacang tanah dan jagung + kangkung.

Pada minggu kedua setelah tanam, perlakuan sistim budidaya jagung pola tunggal menunjukkan tanaman tertinggi, namun tidak berbeda nyata dengan pola tanam jagung + kacang tanah. Tinggi tanaman jagung pada minggu ke ketiga juga tertinggi pada pola tanam tunggal jagung, namun tidak berbeda nyata dengan tanaman jagung + bayam, jagung+ ubijalar, dan jagung + kacang tanah. Tinggi tanaman jagung pola tunggal pada minggu ke empat, pada minggu ke lima dan pada minggu ke enam tertinggi, namun tidak berbeda nyata dengan perlakuan jagung + bayam, jagung + buncis, jagung + ubijalar, jagung + kacang tanah. (Tabel 2).

Hasil analisis pada pertumbuhan tinggi tanaman menunjukkan bahwa tanaman jagung dalam pola tunggal mampu mengasilkan tanaman tertinggi sejak awal pada umur 1 minggu hingga 6 minggu setelah tanam. Hal ini disebabkan karena masih rendahnya persaingan antara tanaman jagung dalam pola tunggal, sehingga kompetisi antar tanaman masih kurang terutama dalam mendapatkan cahaya dan $\mathrm{CO} 2$ dari atmosfir, ruang tumbuh, serta unsur hara dan air dari dalam tanah, baik pada jagung pola tunggal maupun tumpangsari. Pola tanam yang tepat dengan unsur-unsur lingkungan yang optimal di sekitar tanaman akan mendorong pertumbuhan maksimal. 
Tabel 2. Tinggi tana man jagung dalam sistim budidaya pola campuran dengan beberapa jenis tanaman lainnya pada 1-6 minggu setelah tanam

\begin{tabular}{lllllll}
\hline \multirow{2}{*}{ Perlakuan } & \multicolumn{7}{c}{ Tinggi tanaman (cm) } \\
\cline { 2 - 7 } 1 MST & 2 MST & 3 MST & 4 MST & 5 MST & 6 MST \\
\hline Jagung (monokultur) & $5.17 \mathrm{a}$ & $9.77 \mathrm{a}$ & $29.20 \mathrm{a}$ & $53.53 \mathrm{a}$ & $85.60 \mathrm{a}$ & $95.33 \mathrm{a}$ \\
Jagung + Bayam & $4.42 \mathrm{bc}$ & $8.60 \mathrm{~b}$ & $27.47 \mathrm{ab}$ & $51.07 \mathrm{abc}$ & $82.50 \mathrm{ab}$ & $91.90 \mathrm{ab}$ \\
Jagung + Keladi & $4.17 \mathrm{bc}$ & $7.88 \mathrm{bcd}$ & $23.54 \mathrm{bc}$ & $42.83 \mathrm{~cd}$ & $68.83 \mathrm{bcd}$ & $76.58 \mathrm{bcd}$ \\
Jagung + Buncis & $4.29 \mathrm{bc}$ & $8.13 \mathrm{bc}$ & $24.17 \mathrm{bc}$ & $44.27 \mathrm{bcd}$ & $71.10 \mathrm{abc}$ & $79.13 \mathrm{abc}$ \\
Jagung + Ubijalar & $3.92 \mathrm{c}$ & $7.99 \mathrm{bc}$ & $25.12 \mathrm{ab}$ & $46.42 \mathrm{abc}$ & $74.83 \mathrm{ab}$ & $83.44 \mathrm{ab}$ \\
Jagung + Kacang Tanah & $4.54 \mathrm{abc}$ & $9.83 \mathrm{a}$ & $28.53 \mathrm{a}$ & $52.90 \mathrm{ab}$ & $84.93 \mathrm{a}$ & $94.67 \mathrm{a}$ \\
Jagung + Bawang Merah & $3.92 \mathrm{c}$ & $6.90 \mathrm{~d}$ & $18.73 \mathrm{~d}$ & $33.75 \mathrm{e}$ & $54.00 \mathrm{~d}$ & $60.05 \mathrm{~d}$ \\
Jagung + Kangkung & $4.71 \mathrm{ab}$ & $9,30 \mathrm{ab}$ & $20.54 \mathrm{~cd}$ & $37.04 \mathrm{de}$ & $59.33 \mathrm{~cd}$ & $65.83 \mathrm{~cd}$ \\
\hline
\end{tabular}

Keterangan : Angka-angka yang diikuti oleh huruf yang sama pada kolom yang sama tidak berbeda nyata pada uji BNT dengan taraf kepercayaan $95 \%$, MST= minggu setelah tanam

Perlakuan jagung monokultur dan tumpangsari jagung+kacang tanah menunjukan tanaman lebih tinggi dibandingkan kombinasi tumpangsari lainnya. Hal ini diduga karena tanaman jagung memiliki kemampuan dalam menyerap cahaya matahari lebih besar, mengingat bentuk morfologinya lebih tinggi dan tergolong tanaman $\mathrm{C} 4$ yang efisien dalam memanfaatkan cahaya matahari sehingga proses fotosintesis berlangsung efisien dan maksimal (Khalil, 2000) dibandingkan jenis tanaman lain yang ditumpangsarikan. Hasil ini menunjukkan bahwa jagung sebagai tanaman utama menunjukkan dominasinya dalam memanfaatkan faktor tumbuh (Putra et al., 2017). Hal yang kedua, kacang tanah sebagai tanaman pendamping jagung dapat bersimbiosis dengan bakteri Rhizobium sp. dalam bintil akar yang mampu mengikat $\mathrm{N}$ dari atmosfir, sehingga menyediakan $\mathrm{N}$ bagi tanaman. Manfaat dari fiksasi $\mathrm{N}$ oleh bakteri penambat nitrogen berupa ekstrak nitrogen yang dikeluarkan dari bintil akar untuk tanaman yang tumbuh bersama dengan tanaman leguminosa, dan hal ini menguntungkan tanaman jagung yang ditumpangsarikan dengan tanaman kelompok legum seperti kacang tanah. Sehingga adanya saling interaksi yang baik antara tanaman jagung + kacang tanah memberikan hasil yang sangat nyata terhadap tinggi tanaman jagung.

\section{Jumlah Daun}

Tanaman jagung dengan pola tanam tunggal menghasilkan jumlah daun tertinggi sejak umur 1 minggu 6 minggu setelah tanam (Tabel 3). Pada umur 1 MST sistim jagung pola tunggal berbeda nyata dengan pola tumpangsari dengan semua tanaman lainnya. Namun pada umur 2 dan 4, 5 dan 6 MST, sistim tanam jagung pola tunggal tidak berbeda nyata dengan tumpangsari jagung + bayam, jagung + buncis dan jagung + kacang tanah. Pola jagung monokultur dan tumpangsari jagung + bayam, jagung + buncis, jagung + kacang tanah mampu menghasilkan jumlah daun tertinggi pada seluruh waktu pengamatan. Menurut Yuwariah et al. (2017), pada pola tumpangsari tanaman jagung dan kedelai, tanaman jagung lebih unggul dalam persaingan menyerap air, unsur hara, cahaya dan pertumbuhan akar. 
Table 3. Jumlah daun tanaman jagung dalam sistim tanam pola campuran dengan beberapa jenis tanaman lainnya pada 1-6 minggu setelah tanam

\begin{tabular}{lllllll}
\hline \multirow{2}{*}{ Perlakuan } & \multicolumn{7}{c}{ Jumlah daun per tanaman } \\
\cline { 2 - 7 } & 1 MST & 2 MST & 3 MST & 4 MST & 5 MST & 6 MST \\
\hline Jagung (monokultur) & $3.79 \mathrm{a}$ & $4.09 \mathrm{a}$ & $6.25 \mathrm{a}$ & $9.04 \mathrm{a}$ & $12.70 \mathrm{a}$ & $13.63 \mathrm{a}$ \\
Jagung + Bayam & $2.46 \mathrm{bc}$ & $3.92 \mathrm{ab}$ & $5.42 \mathrm{~b}$ & $8.21 \mathrm{ab}$ & $12.33 \mathrm{a}$ & $13.53 \mathrm{a}$ \\
Jagung + Keladi & $2.08 \mathrm{c}$ & $2.46 \mathrm{~d}$ & $4.46 \mathrm{~cd}$ & $7.17 \mathrm{bc}$ & $10.79 \mathrm{bc}$ & $11.67 \mathrm{bc}$ \\
Jagung + Buncis & $2.42 \mathrm{bc}$ & $3.05 \mathrm{bcd}$ & $5.06 \mathrm{bc}$ & $8.08 \mathrm{ab}$ & $12.10 \mathrm{ab}$ & $13.10 \mathrm{ab}$ \\
Jagung + Ubi Jalar & $2.29 \mathrm{c}$ & $2.84 \mathrm{~cd}$ & $4.59 \mathrm{~cd}$ & $7.25 \mathrm{bc}$ & $10.77 \mathrm{bc}$ & $11.73 \mathrm{bc}$ \\
Jagung + Kacang Tanah & $2.96 \mathrm{~b}$ & $3.37 \mathrm{abc}$ & $5.38 \mathrm{~b}$ & $8.21 \mathrm{ab}$ & $11.87 \mathrm{ab}$ & $12.77 \mathrm{ab}$ \\
Jagung + Bawang Merah & $2.21 \mathrm{c}$ & $2.33 \mathrm{~d}$ & $4.21 \mathrm{~d}$ & $6.32 \mathrm{c}$ & $9.25 \mathrm{~d}$ & $9.88 \mathrm{~d}$ \\
Jagung + Kangkung & $2.58 \mathrm{bc}$ & $2.38 \mathrm{~d}$ & $4.42 \mathrm{~cd}$ & $6.92 \mathrm{c}$ & $10.25 \mathrm{~cd}$ & $11.08 \mathrm{~cd}$ \\
\hline
\end{tabular}

Keterangan : Angka-angka yang diikuti oleh huruf yang sama pada kolom yang sama tidak berbeda nyata pada uji BNT dengan taraf kepercayaan $95 \%$, MST= minggu setelah tanam

Persaingan antar jenis tanaman maupun antar individu satu dengan individu lainnya pada satu jenis tanaman merupakan salah satu faktor yang mempengaruhi pertumbuhan tanaman dalam sistim tumpangsari dalam perebutan unsur-unsur hara, air, dan cahaya sehingga pertumbuhan dan perkembangan tanaman menjadi rendah atau terhambat pada tanaman yang kalah bersaing.

Pada Tabel 3 menunjukkan bahwa tanaman jagung yang ditanam dalam pola tumpangsari dengan tanaman buncis dan kacang tanah menghasilkan jumlah daun yang relatif sebanding dengan sitim tanam tunggal. Hal ini diduga karena tercukupinya unsur $\mathrm{N}$ yang disumbangkan oleh tanaman buncis dan kacang tanah. Kedua tanaman tersebut merupakan kelompok tanaman legume yang mampu memberikan kontribusi pada ketersediaan unsur $\mathrm{N}$ dari hasil kerjasama dengan bakteri penambat $\mathrm{N}$, sehingga mampu mencukupi kebutuhan hara untuk pertumbuhan tanaman (Myrna, 2006). Sejalan dengan penelitian Rosmarkam dan Yuwono (2002) dengan adanya unsur N maka tanaman akan membentuk bagian bagian vegetatif termasuk pembentukan daun. Nitrogen diperlukan untuk merangsang pertumbuhan vegetatif tanaman, seperti daun, batang dan akar, termasuk meningkatkan dan menyehatkan pertumbuhan daun (Sutedjo, 1999). Demikian pula menurut Warman dan
Kristiana (2018), tanaman semusim yang ditanam bersamaan dengan jenis tanaman kacang-kacangan akan memberikan hasil yang lebih baik karena tanaman kacangkacangan mampu mengikat nitrogen sehingga dapat dimanfaatkan oleh tanaman yang berada disekitarnya.

Tumpangsari jagung + bayam memiliki jumlah daun yang tinggi dibandingkan dengan beberapa perlakuan tumpangsari lainnya diduga karena tanaman bayam berumur pendek, dipanen pada umur 1,5 bulan setelah tanam, sehingga kompetisi antara bayam dan jagung baik dalam penangkapan cahaya, fiksasi $\mathrm{CO} 2$ untuk fotosintesis, penyerapan air, dan unsur hara untuk berbagai proses metabolism sangat minimal. Selanjutnya bila dilihat dari sistem perakaran, tanaman bayam mempunyai kedalam perakaran 20$60 \mathrm{~cm}$ sedangkan jagung mempunyai kedalam perakaran lebih dalam (Kusumasiwi 2011), sehingga jagung lebih komptetitif dalam mengektrak air dan hara.

Hasil fotosintesis akan didistribusi pada bagian atas dan bawah organ tanaman. Pergerakan ke atas akan membantu pertumbuhan tajuk (pucuk, daun dan batang) sehingga tanaman akan lebih tinggi dan jumlah daun akan bertambah. Selain itu faktor yang mempengaruhi pertumbuhan jumlah daun adalah kandungan klorofil daun. Kandungan klorofil daun bayam lebih tinggi sehingga memungkinkan pembagian 
cahaya lebih merata antar daun dan mengurangi kejadian saling menaungi (Sulistyaningsih et al., 2005).

\section{Diameter Batang}

Hasil uji Beda Nyata Terkecil (BNT) pada variabel diameter batang (Tabel 4) menunjukkan bahwa pada minggu kelima setelah tanam perlakuan jagung (kontrol), jagung + bayam, jagung + ubijalar, jagung + kacang tanah memiliki diameter batang yang lebih basar dibandingkan dengan perlakuan lainnya dan tidak berbeda nyata. Sedangkan sistim tanam pola jagung tunggal berbeda nyata dengan perlakuan sistim tanam pola campuran yaitu jagung + keladi, jagung + buncis, jagung + bawang merah dan jagung + kangkung. Diameter yang lebih besar diduga karena kontribusi senyawa nitrogen terutama dari tanaman kacang tanah. Dari segi kelengkapan nutriennya, tanaman jenis legum dapat merupakan suplemen sumber protein yang dapat melengkapi nutrien pada tanaman serealia yang dibudidayakan bersamasama (Dahmardeh et al., 2009).

Nitrogen digunakan oleh tanaman untuk membentuk asam amino yang akan diubah menjadi protein. Nitrogen juga dibutuhkan untuk membentuk senyawa penting seperti klorofil, asam nukleat dan enzim. Oleh karena itu, nitrogen sangat dibutuhkan tanaman pada setiap tahap pertumbuhan, khususnya pada tahap pertumbuhan vegetative seperti pembentukan tunas, dun dan perkembangan batang (Novisan, 2002). Sedangkan pada pada sistim budidaya pola campuran, perlakuan kombinasi tanaman menunjukan diameter batang lebih kecil dikarenakan adanya persaingan unsur hara, air dan naungan. Mayadewi (2007) menambahkan bahwa ketersediaan $\mathrm{N}$ di awal pertumbuhan juga sangat mempengaruhi fase pertumbuhan dan perkembangan berikutnya seperti penyerbukan dan pengisian biji serta peningkatan berat segar tongkol.

\section{Berat Brangkasan Kering Tanaman}

Pada Tabel 4 tampak bahwa perlakuan sistim budidaya tunggal dan pola campuran tidak berpengaruh nyata terhadap berat brangkasan kering tanaman.

Table 4. Rata-rata diameter batang pada umur 6 minggu setelah tanam dan berat brangkasan kering tanaman jagung pada saat panen dalam sistim tumpangsari jagung dengan beberapa jenis tanaman semusim lainnya

\begin{tabular}{lcc}
\hline Perlakuan & Diameter batang (mm) & $\begin{array}{c}\text { Berat brangkasan kering tanaman } \\
\text { (gr/tanaman) }\end{array}$ \\
\hline Jagung (monokultur) & $18.88 \mathrm{a}$ & 66.12 \\
Jagung + Bayam & $18.88 \mathrm{a}$ & 58.07 \\
Jagung + Keladi & $11.17 \mathrm{~b}$ & 70.38 \\
Jagung + Buncis & $16.00 \mathrm{a}$ & 66.78 \\
Jagung + Ubi Jalar & $18.33 \mathrm{a}$ & 75.48 \\
Jagung + Kacang Tanah & $18.88 \mathrm{a}$ & 72.01 \\
Jagung + Bawang Merah & $9.46 \mathrm{~b}$ & 73.09 \\
Jagung + Kangkung & $9.83 \mathrm{~b}$ & 67.29 \\
\hline
\end{tabular}

Keterangan : Angka-angka yang diikuti oleh huruf yang sama pada kolom yang sama tidak berbeda nyata pada uji BNT dengan taraf kepercayaan $95 \%$.

\section{Panjang, Diameter dan Bobot Tongkol Jagung}

Hasil penelitian pada komponen hasil berupa tongkol jagung tanpa kelobot tidak menunjukkan pengaruh yang nyata pada perlakuan sistim budidaya jagung tunggal dan tumpangsari antara jagung dengan berbagai tanaman pendamping terhadap panjang, diameter dan bobot tongkol jagung tanpa kelobot (Tabel 5). 
Tabel 5. Rata-rata panjang tongkol, diameter tongkol dan bobot jagung tanpa kelobot pada saat panen

\begin{tabular}{lccc}
\hline Perlakuan & $\begin{array}{c}\text { Panjang tongkol } \\
\text { tanpa kelobot }(\mathbf{c m})\end{array}$ & $\begin{array}{c}\text { Diameter tongkol } \\
\text { tanpa kelobot }(\mathbf{c m})\end{array}$ & $\begin{array}{c}\text { Bobot tongkol tanpa } \\
\text { kelobot } \\
\text { (gr/tongkol/tanaman) }\end{array}$ \\
\hline Jagung (monokultur) & 17.54 & 4.34 & 198.06 \\
Jagung + Bayam & 19.46 & 4.71 & 221.51 \\
Jagung + Keladi & 18.67 & 4.48 & 201.36 \\
Jagung + Buncis & 16.00 & 4.60 & 198.47 \\
Jagung + Ubi Jalar & 19.13 & 4.62 & 234.12 \\
Jagung + Kacang Tanah & 18.63 & 4.42 & 208.37 \\
Jagung + Bawang Merah & 19.19 & 4.72 & 218.95 \\
Jagung + Kangkung & 20.42 & 4.71 & 245.27 \\
\hline
\end{tabular}

Keterangan : Angka-angka yang diikuti oleh huruf yang sama pada kolom yang sama tidak berbeda nyata pada uji BNT dengan taraf kepercayaan $95 \%$

Pada fase pertumbuhan vegetatif, pola tanam jagung tunggal pada variabel pertumbuhan (tinggi tanaman, jumlah daun dan diameter batang) lebih tinggi dibandingkan pola tumpangsari dengan beberapa jenis tanaman semusim lainnya (Tabel 2, 3 dan 4). Sebaliknya pada pola tumpangsari antara jagung dengan tanaman semusim lainnya memiliki panjang tongkol, diameter tongkol dan bobot tongkol lebih tinggi. Hasil ini menunjukkan bahwa tanaman jagung mampu bersaing dalam memanfaatkan unsur lingkungan untuk memaksimalkan pertumbuhan generatif dengan jenis tanaman lainnya pada tumpangsari dengan tanaman sayuran daun berumur pendek (35 minggu) seperti kangkung yang dipanen pada umur 4 minggu setelah tanam, dengan menghasilkan bobot tongkol jagung tertinggi (245,27 gr/tongkol), dan tumpangsari jagung + bayam yang dipanen saat bayam berumur 5 minggu setelah tanam menghasilkan bobot tongkol 221,51 gr/tongkol (Tabel 5). Kangkung darat memiliki batang dengan bentuk daun runcing. Menurut Warman dan Kristiana (2018), morfologi tanaman masing-masing spesies yang berbeda akan mempengaruhi interaksi antar tanaman yang ditanam dalam bidang yang sama. Hasil ini selaras dengan Surtinah et al. (2016) bahwa tumpangsari antara tanaman jagung dan kangkung tidak mempengaruhi hasil jagung, hal ini diduga karena keberadaan tanaman kangkung tidak mengganggu ketersediaan hara yang dibutuhkan oleh jagung.

Jagung yang ditumpangsarikan dengan tanaman buncis, kacang tanah, bawang merah yang dipanen pada umur 10-12 minggu serta tumpangsari jagung dengan keladi dan ubijalar menghasilkan berat tongkol jagung lebih rendah dibandingkaan tanaman jagung yang ditumpangsarikan dengan tanaman sayuran daun berumur pendek (kangkung dan bayam). Hasil ini menunjukkan bahwa sejalan dengan bertambahnya umur tanaman maka interaksi dan persaingan tanaman dalam mendapatkan hara maupun unsur-unsur lingkungan lainnya antara tanaman jagung dan tanaman pendamping yang berumur panjang akan semakin tinggi. Hal ini berdampak pada lebih rendahnya hasil berat tongkol jagung yang dipanen bersamaan waktunya dengan tanaman semusim lainnya yang berumur relatif sama atau lebih panjang.

Berat tongkol jagung yang ditumpangsarikan dengan kacang tanah dan buncis lebih tinggi bila dibandngkan dengan berat tongkol jagung pada pola monokultur. Tanaman kacang tanah dan 
buncis tergolong tanaman leguminosa yang mampu bersimbiosis dengan bakteri Rhizobium sp., dan menyumbang unsur $\mathrm{N}$ dari hasil fiksasi bakteri tersebut ke dalam tanah (Suryotomo et al., 2015; Samosir et al., 2019), sehingga diduga memberikan kontribusi lebih dalam mendorong pertumbuhan dan hasil tanaman jagung. Sebagaimana menurut Vandermeer (1989) bahwa pertanaman tumpangsari akan menimbulkan terjadinya kompetisi antar jenis-jenis tanaman yang ditumpangsarikan terhadap air, hara, dan radiasi surya, namun juga memberikan peluang terjadinya interaksi yang positif (menguntungkan) antara kedua jenis tanaman sehingga memberikan produktivitas yang lebih tinggi. Menurut Warman dan Kristiana, (2018), dalam pola tumpangsari maka interaksi tanaman yang satu dengan tanaman lainnya akan mempengaruhi pertumbuhan tanaman di lingkungan tersebut, sehingga karakter setiap tanaman yang ditumpangsarikan baik dari aspek morfologi maupun fisiologi penting untuk diketahui.

\section{KESIMPULAN}

Tanaman jagung dalam pola monokultur menunjukkan pertumbuhan tertinggi pada komponen pertumbuhan vegetative (tinggi tanaman, jumlah daun dan diameter batang), namun pada komponen hasil/produksi menunjukkan rata-rata bobot tongkol per tanaman terendah. Dalam pola tumpangsari, kombinasi tumpangsari jagung + kacang tanah menghasilkan tanaman tertinggi, tumpangsari jagung + bayam dan tumpangsari jagung + buncis menghasilkan jumlah daun lebih banyak. Tumpangsari jagung + bayam, jagung + buncis, jagung + ubijalar dan jagung + kacang tanah menghasilkan diameter batang lebih besar.

Pada komponen hasil/produksi (ratarata panjang tongkol, diameter tongkol dan berat tongkol per tanaman) secara statistik tidak dipengaruhi oleh perlakuan pola budidaya tunggal dan tumpangsari, namun terlihat bahwa tumpangsari jagung+kangkung menghasilkan berat tongkol pertanaman tertinggi.

\section{SUMBER DANA PENELITIAN}

Dana Bantuan operasional perguruan tinggi negeri (BOPTN).

\section{DAFTAR PUSTAKA}

BPS Papua Barat. 2015. Papua Barat Dalam Angka. Badan Pusat Statistik (BPS) Papua Barat.

Coolman, R.M., \& Hoyt, G.D. (1993). Increasing Sustainability by Intercropping. Hort. Technology, 3(3), 309-312.

Dahmardeh, M., Ghanbari A., Syasar, B., \& Ramroudi, M. (2009). Effect of Intercropping Maize (Zea mays L.) with Cowpea (Vigna unguiculata L.) on Green Forage Yield and Quality Evaluation. Asian Journal of Plant Science, 8, 235-239. DOI: 10.3923/ajps.2009.235.239

Ekayujaya. (2019). Turiman, Efisiensi dan Solusi Angkat Produktifitas Lahan. BPTP. Kaltim. Badan Litbang Pertanian-Kementerian PertanianRepublik Indonesia. http://kaltim.litbang.pertanian.go.id/ ind/index.php?option $=$ com content $\&$ view $=$ article $\&$ id $=1122 \&$ Itemid $=5$ Diakses pada tanggal 2 Juni 2021.

Herlina. (2011). Kajian Variasi Jarak Tanam dan Waktu Tanam Jagung Manis Dalam Sistem Tumpangsari Jagung Manis (Zea mays saccharata Sturt) dan Kacang Tanah (Arachis hypogaea L.) Andalas. Program Pasca Sarjana Universitas Andalas. Padang. https://www.academia.edu/6446736 Diakses 3 Januari 2021.

Kementerian Pertanian RI. 2016. Produksi jagung Indonesia 2016 diperkirakan tertinggi di Asia Tenggara. 
https://www.pertanian.go.id/home/?s how $=$ news\&act $=$ view\&id $=1591$

Diakses pada tanggal 1 Juni 2021.

Khalil, M. (2000). Penentuan Waktu Tanam Kacang Tanah dan Dosis Pupuk Posfat Terhadap Pertumbuhan, Hasil Kacang Tanah dan Jagung Dalam Sistem Tumpang Sari. Agrista. 4(3), 259-265.

Kusumasiwi, A.W.P. (2011). Pengaruh Warna Plastik terhadap Pertumbuhan dan Hasil Terung (Solanum melongena L.) Tumpangsari dengan Kangkung Darat (Ipomea reptans Poir.). Skripsi. Fakultas Pertanian. Universitas Gadjah Mada.

Mayadewi, N.N.A. (2007). Pengaruh Jenis Pupuk Kandang dan Jarak Tanam Terhadap Pertumbuhan Gulma dan Hasil Tanaman Jagung Manis. J. Agritrop, 26(4), 153-159.

Myrna, N.E.F. (2006). Hasil Tanaman Jagung Pada Berbagai Dosis dan Cara Pemupukan N Pada Lahan Dengan Sistem Olah Tanah Minimum. J. Agronomi, 9 (1).

Novizan. (2002). Penunjuk Pemupukan Efektif. Jakarta. Agromedia.

Passioura, J.B. (2002). Environmental Biology and Crop Improvement. Func. Plant Biology, 29, 537-546

Prasetyo, E.I., Sukardjo, \& Pujiwati, H. (2009). Produktifitas Lahan dan NKL Pada Tumpangsari Jarak Pagar Dengan Tanaman Pangan. Jurnal Akta Agrosia, 12(1), 51-55.

Putra, J.P.H., Wicaksono, K.P., \& Herlina, N. (2017). Studi Sistem Tumpangsari Jagung (Zea mays L.) dan Bawang Prei (Allium porrum L.). Jurnal Produksi Tanaman, 5(5), 748-755.

Rosmarkam, A. \& Yuwono, N.W. (2002). Ilmu Kesuburan Tanah. Yogyakarta. Kanisius.

Samosir, O.M., Marpaung, R.G., \& Laia, T. (2019). Respon Kacang Tanah (Arachis hypogaea L) Terhadap Pemberian Unsur Mikro. Jurnal
Agrotekda, 3(2), 74-83.

Santia, T. 2021. Daftar 10 Propinsi Penghasil Jagung Terbesar Indonesia, Mana Saja?. https://www.liputan6.com/bisnis/rea d/4449535/daftar-10-provinsipenghasil-jagung-terbesarindonesia-mana-saja Diakses 1 Juni 2021.

Sullivan, P. (2003). Intercropping Principles and Production Practices: Agronomy System Guide. http://attra.ncat.org/attrapub/PDF/intercrop.pdf Diakses tanggal 5 Mei 2020.

Sulistyaningsih, E., Kurniasih, B., \& Kurniasih, E. (2005). Pertumbuhan dan Hasil Caisin Pada Berbagai Warna Sungkup Plastik. Jurnal Ilmu Pertanian, 12(1): 65-76.

Surtinah, Susi, N., \& Lestari, S.U. (2016). Optimasi Lahan dengan Sistem Tumpang Sari Jagung Manis (Zea mays saccharata, Sturt) dan Kangkung Sutra (Ipomea reptans) di Pekanbaru. Jurnal Ilmiah Pertanian, 12(2), 61-71.

Suryotomo, B., Fauzan, A., \& Nuryani, T. (2015). Aplikasi Berbagai Macam Legin dan Saat Defoliasi Pada Tanaman Buncis (Phaseolus vulgaris L.). Prosiding Seminar Nasional Pangan, Energi, dan Lingkungan 2015. Kontribusi Bidang Pangan, Energi, dan Lingkungan di Indonesia dalam Menghadapi MEA (Masyarakat Ekonomi ASEAN).

Sutedjo, M.M. (1999). Pupuk dan Cara Pemupukan. Jakarta. Rineka Cipta.

Vandermeer, J. (1989). The Ecology on Intercropping. Cambridge University. Press. New York.

Warman, GR., \& Kristiana, R. (2018). Mengkaji Sistem Tanam Tumpangsari Tanaman Semusim. Proceeding Biology Education Conference. 15(1),791-794.

Warsana. (2009). Introduksi Teknologi 
Tumpang Sari Jagung dan Kacang tanah. BPTP Jawa Tengah.

Yuwariah, Y., Ruswandi, D., \& Irwan A.W. (2017). Pengaruh Pola Tanam Tumpangsari Jagung dan Kedelai Terhadap Pertumbuhan dan Hasil Jagung Hibrida dan Evaluasi Tumpangsari di Arjasari Kabupaten Bandung. Jurnal Kultivasi, 16(3), 514-521.

Zulkarnain. (2005). Pertumbuhan dan Hasil Selada Pada Berbagai Kerapatan Jagung Dalam Pola Tumpangsari. Jurnal Ilmu-ilmu Pertanian, 1(2), 94-101. 